\title{
Pengaruh Pemberian Fraksi Daun Kemangi (Ocimum americanum L.) terhadap Berat, Diameter, Tebal Epitel Epididimis, Motilitas dan Viabilitas Spermatozoa Tikus Putih Jantan (Rattus norvegicus)
}

\author{
Stephanie Lexy Louis ${ }^{1}$, Salni $^{2}$, Sri Nita $^{3}$ \\ ${ }^{1}$ Fakultas Ilmu Kesehatan, Universitas Katolik Musi Charitas Palembang, Indonesia \\ ${ }^{2,3}$ Fakultas Kedokteran, Universitas Sriwijaya, Indonesia \\ Email: stephanielexy5513@gmail.com
}

\begin{abstract}
The Effect of Feeding Fractions of Kemangi Leaves (Ocimum americanum L.) on The Epididymis Weight, Diameter, Epithelium Thickness, Motility and Viability Spermatozoa of Male White Rat (Rattus norvegicus). Infertility is one of the reproductive problems that may affect both male and female. In a male, the occurrence of reproductive problems may be due to abnormal spermatogenesis processes and anatomic disorder. Kemangi leaves are an aphrodisiac it contains some secondary metabolites like flavonoid, steroid, tannin, and saponin. The objective of the present research was to determine the effect of feeding fractions of kemangi leaves (Ocimum americanum L.) on the epididymis weight, diameter, and epithelial thickness and the spermatozoa motility and viability of white male rat (Rattus norvegicus). The research was an experimental one, with posttest only group design. The research design used a Completely Random Design. The research sample consisted of 24 furrow white male mice Sprague Dawley, 60-74 days old, divided to control group, a fraction of $n$-hexane, a fraction of ethyl acetate, and a fraction of water-ethanol. The dosage used for the treatment group was 100 $\mathrm{mg} / \mathrm{kgBB} /$ day, and the control group was given CMC $1 \%$. The result of data analysis by using a One-Way Anova test showed that there were increases in the weight and diameter of the epididymis in the treatment group as compared to that of the control group $(p=0,000)$. Likewise, both epididymis epithelium thickness and spermatozoa viability in the treatment group increased as compared to that of the control group $(\mathrm{p}=0.001)$, while spermatozoa motility was $\mathrm{p}=0,002$. It could be concluded that the fractions of kemangi leaves increased the weight, diameter, and epithelium thickness of epididymis and spermatozoa motility and viability in-furrow white male rat Sprague Dawley.
\end{abstract}

Keywords: Epididymis, Fraction of Kemangi Leaves, Spermatozoa

\begin{abstract}
Abstrak: Pengaruh Pemberian Fraksi Daun Kemangi (Ocimum americanum L.) terhadap Berat, Diameter, Tebal Epitel Epididimis, Motilitas dan Viabilitas Spermatozoa Tikus Putih Jantan (Rattus norvegicus). Infertilitas merupakan salah satu masalah reproduksi yang dapat terjadi pada pria maupun wanita. Pada pria, terjadinya infertilitas dipengaruhi oleh proses spermatogenesis abnormal dan kelainan anatomi. Daun kemangi merupakan tanaman yang bersifat afrodisiak dan terdapat kandungan metabolit sekunder seperti flavonoid, steroid, tanin dan saponin. Tujuan penelitian mengetahui pengaruh pemberian fraksi daun kemangi (Ocimum americanum L) terhadap berat, diameter, tebal epitel epididimis, motilitas dan viabilitas spermatozoa tikus putih jantan (Rattus norvegicus). Desain penelitian eksperimental dengan post test only group design. Rancangan penelitian menggunakan Rancangan Acak Lengkap (RAL). Sampel yang digunakan sebanyak 24 ekor tikus putih jantan galur Sprague Dawley, usia 60-74 hari, yang terdiri dari kelompok kontrol, fraksi n-heksan, fraksi etil asetat, dan fraksi etanol air. Dosis yang digunakan pada kelompok perlakuan adalah $100 \mathrm{mg} / \mathrm{kgBB} / \mathrm{hr}$, kelompok kontrol diberikan CMC 1\%. Analisis data dengan uji One Way Anova menunjukkan adanya peningkatan berat, diameter epididimis pada kelompok perlakuan dibandingkan kelompok kontrol $(p=0,000)$. Tebal epitel epididimis dan viabilitas spermatozoa pada kelompok perlakuan mengalami peningkatan dibandingkan kelompok kontrol $(p=0,001)$, sedangkan pada motilitas spermatozoa $(p=0,002)$. Fraksi daun kemangi dapat meningkatkan berat, diameter, tebal epitel epididimis, motilitas dan viabilitas spermatozoa pada tikus putih jantan galur Sprague Dawley.
\end{abstract}

Kata kunci: Epididimis, Fraksi Daun Kemangi, Spermatozoa 


\section{PENDAHULUAN}

Pasangan infertil di Indonesia tahun 2013 sejumlah 50 juta pasangan atau $15-20 \%$ dari seluruh pasangan yang ada (Riskesdas, 2013). Faktor pria bertanggung jawab sebesar $36 \%$ sedangkan pada wanita sebesar $64 \%$ yang diperkirakan sekitar 50-80 juta pasutri (1 dari 7 pasangan) mengalami infertilitas sehingga setiap tahun ada sekitar 2 juta pasangan infertil (WHO, 2010).

Pada pria, proses spermatogenesis dipengaruhi oleh hormon-hormon yang dihasilkan oleh organ hipotalamus, hipofisis dan testis. Pengaturan pembentukan spermatogenesis dimulai dengan sekresi GnRH oleh hipotalamus. Hormon ini akan merangsang kelenjar hipofisis anterior untuk menyekresikan dua hormon lain yaitu Follicle Stimulating Hormone (FSH) yang berfungsi merangsang pertumbuhan testis dan meningkatkan protein pengikat androgen oleh sel sertoli dan Luteinizing Hormone (LH) yang berperan untuk merangsang sekresi testosteron (Naz et al, 2006).

Sistem reproduksi pria yang berperan dalam proses spermatogenesis yaitu epididimis yang merupakan saluran spermatozoa panjang dan berbelit dan terdapat bagian kaput, korpus, dan kauda (Cornwall, 2009). Pada cauda epididimis merupakan tempat penyimpanan spermatozoa dalam jumlah besar sekitar $75 \%$ (Wahyuni et al, 2012). Epididimis berfungsi sebagai tempat pematangan sperma, menyimpan sperma dan tempat transportasi spermatozoa ke duktus deferens (Jones, 2004).

Indonesia dikenal sebagai sumber bahan baku obat-obatan tropis yang bermanfaat untuk mengatasi berbagai macam penyakit. Menurut Siburian dkk (2009), tanaman yang berpotensi afrodisiak menunjukkan adanya peningkatan jumlah sel-sel spermatogenik yang meningkatkan fertilitas pada pria. Salah satu tumbuhan yang dapat digunakan sebagai antioksidan alami adalah tanaman dari Genus Ocimum yaitu tanaman kemangi yang termasuk ke dalam family Lamiaceae dan dikenal dengan istilah Queen of herb dikarenakan banyaknya manfaat tanaman tersebut bagi kesehatan (Balaji et al, 2011).

Pada daun kemangi terdapat beberapa kandungan metabolit sekunder lainnya seperti minyak atsiri, fitosterol, alkaloid, tanin, lignin, saponin, flavonoid, dan terpenoid (Sarma et al, 2011). Dari beberapa penelitian diketahui bahwa kandungan flavonoid sebagai antioksidan dapat meningkatkan kualitas sperma dengan cara mencegah adanya kerusakan membran spermatozoa (Palupi, 2006).
Beberapa penelitian yang telah dilakukan pada daun kemangi (Ocimum americanum L.) menunjukkan adanya fertilitas. Hal ini ditunjukkan dengan penelitian Safwan (2016) bahwa penggunaan ekstrak daun kemangi (Ocimum americanum L.) yang diberikan selama 20 hari dengan dosis $50 \mathrm{mg} / \mathrm{kgBB}, 100 \mathrm{mg} / \mathrm{kgBB}$ dan $250 \mathrm{mg} / \mathrm{kgBB}$ secara signifikan dapat meningkatkan motilitas dan konsentrasi spermatozoa mencit jantan.

\section{METODE}

Penelitian ini merupakan penelitian eksperimental yang dilakukan selama 36 hari, bertempat di Laboratorium Bagian Biologi Kedokteran FK Universitas Sriwijaya dan Laboratorium Patologi Anatomi Dyatnitalis. Rancangan penelitian yang digunakan adalah Rancangan Acak Lengkap (RAL). Hewan uji yang digunakan dalam penelitian ini adalah tikus putih jantan strain Sprague Dawley usia 60-74 hari sebanyak 24 ekor dengan berat badan 210220 gram yang diperoleh dari Peternakan Bandung. Tikus diadaptasi selama 7 hari di animal house FK Universitas Sriwijaya.

Alat yang digunakan dalam penelitian ini meliputi timbangan analitik, mikroskop Olympus (tipe CX31), vacuum rotary evaporator, beaker glass, object glass, spatula stainless, cawan petri, pinset, pisau \& gunting bedah, labu ukur, cassette, cooling plate, sokhlet, microtome, shadon, micrometer okuler, water bath. Bahan yang digunakan yaitu simplisia daun kemangi, pakan tikus, larutan n-heksan, etil asetat, etanol $96 \%$, NaCL 0,9\%, CMC 1\%, alkohol 70\%, Eosin $1 \%$, aquades.

Tikus dibagi menjadi 4 kelompok antara lain, kelompok kontrol $\left(\mathrm{K}_{1}\right)$ diberikan CMC $1 \%$ $2 \mathrm{ml}$ secara oral $1 \mathrm{x} /$ hari. kelompok perlakuan 1 $\left(\mathrm{P}_{1}\right)$ diberikan fraksi $\mathrm{n}$-heksan daun kemangi (Ocimum americanum L.) dengan dosis $100 \mathrm{mg} / \mathrm{kgBB} / \mathrm{hari}$, kelompok perlakuan $2\left(\mathrm{P}_{2}\right)$ diberikan fraksi etil asetat daun kemangi (Ocimum americanum L.) $100 \mathrm{mg} / \mathrm{kgBB} / \mathrm{hari}$, dan kelompok perlakuan $3\left(\mathrm{P}_{3}\right)$ diberikan fraksi etanol air daun kemangi (Ocimum americanum L. ) $100 \mathrm{mg} / \mathrm{kgBB} / \mathrm{hari}$.

Simplisia daun kemangi (Ocimum americanum L.) sebanyak $1 \mathrm{~kg}$ dimaserasi dengan pelarut etanol sebanyak 4 liter selama 2x24 jam sebanyak dua kali pengulangan kemudian dilakukan penyaringan dan didapatkan hasil $2750 \mathrm{ml}$. Maserat dievaporasi menggunakan vacuum rotary evaporator dan water bath diisi air kemudian dipanaskan hingga suhu $70^{\circ} \mathrm{C}$ untuk 
memisahkan pelarut etanol $96 \%$ dengan ekstrak daun kemangi sehingga didapatkan hasil ekstraksi yang lebih pekat sebanyak $600 \mathrm{ml}$.

Proses fraksinasi yang dilakukan dengan metode fraksi cair-cair (FCC) untuk memisahkan senyawa berdasarkan tingkat kepolaran. Dalam tahapan ini, ekstrak daun kemangi (Ocimum americanum L.) ditambahkan aquadest sebanyak $600 \mathrm{ml}$ (1:1). Selanjutnya, ditambahkan pelarut $\mathrm{n}$-heksan $3 \mathrm{~L}$ dengan 4 kali pengulangan $(4 \times 750$ $\mathrm{ml}$ ) hingga homogen.

Fraksi etanol dan n-heksan dipisahkan dengan labu pemisah sehingga diperoleh fraksi nheksan lalu dievaporasi dengan vacuum rotary evaporator dan di hair dryer hingga fraksi berbentuk pasta.

Fraksi etanol air ditambahkan pelarut etil asetat sebanyak $1,5 \mathrm{~L}$ dengan 3 kali pengulangan $(3 \times 500 \mathrm{ml})$ hingga homogen, kemudian dipisahkan dengan labu pemisah sehingga diperoleh fraksi etil asetat dan fraksi etanol lalu dievaporasi dan di hair dryer hingga fraksi berbentuk pasta.

Tahap akhir diperoleh tiga fraksi yaitu nheksan, etil asetat, etanol. Masing-masing fraksi dimasukkan di wadah dan dilakukan penimbangan dengan timbangan analitik untuk mengetahui berat fraksi.

\section{HASIL}

Tabel 1. Hasil Fraksinasi Daun Kemangi

\begin{tabular}{lrr}
\hline \multicolumn{1}{c}{ Pelarut } & $\begin{array}{c}\text { Berat Fraksi } \\
(\mathbf{g})\end{array}$ & $\begin{array}{c}\text { Persen Berat } \\
(\boldsymbol{\%})\end{array}$ \\
\hline N-Heksan & 46 & 32,01 \\
Etil asetat & 38,3 & 26,65 \\
Etanol air & 59,4 & 41,33 \\
\hline Total & 143,7 & 100,00 \\
\hline
\end{tabular}

Berdasarkan Tabel 1, terlihat bahwa hasil fraksinasi dari ekstrak etanol daun kemangi (Ocimum americanum L.) diperoleh fraksi etanol air berjumlah 59,4 gram (41,33\%) sebagai pelarut polar, sedangkan fraksi n-heksan berjumlah 46 gram $(32,01 \%)$ sebagai pelarut non polar dan fraksi etil asetat didapatkan 38,3 gram $(26,65 \%)$ sebagai pelarut semi polar.

Tabel 2. Penentuan Golongan Senyawa

\begin{tabular}{lccc}
\hline Pelarut & $\begin{array}{c}\text { Fraksi } \\
\text { N-Heksan }\end{array}$ & $\begin{array}{c}\text { Fraksi } \\
\text { Etil Asetat }\end{array}$ & $\begin{array}{c}\text { Fraksi } \\
\text { Etanol Air }\end{array}$ \\
\hline Alkaloid & - & - & - \\
Steroid & - & + & + \\
Terpenoid & - & + & + \\
\hline Tanin & + & - & - \\
\hline Saponin & + & + & + \\
\hline Flavonoid & + & + & + \\
\hline Keterangan : (+) terdeteksi; (-) tidak terdeteksi &
\end{tabular}

Berdasarkan Tabel 2, penapisan uji fitokimia pada fraksi n-heksan terdapat kandungan metabolit sekunder meliputi senyawa tanin, saponin, flavonoid. Pada fraksi etil asetat terdapat senyawa metabolit sekunder berupa steroid, terpenoid, saponin dan flavonoid. Sedangkan pada fraksi etanol air terdapat steroid, terpenoid, saponin dan flavonoid. Dari ketiga fraksi tersebut, ditemukan senyawa yang paling aktif dan terdapat di seluruh fraksi yaitu flavonoid.

\begin{tabular}{|c|c|c|c|c|}
\hline Kelompok & Perlakuan & $\mathrm{n}$ & $\begin{array}{c}\text { BB Tikus (mg) } \\
\overline{\mathbf{x}} \pm S D\end{array}$ & $\begin{array}{c}p- \\
\text { value }\end{array}$ \\
\hline $\mathrm{K}_{1}$ & CMC $1 \%$ & 6 & $210,28 \pm 0,11$ & \multirow{4}{*}{0,326} \\
\hline $\mathrm{P}_{1}$ & $\begin{array}{l}\text { Fraksi n-heksan } \\
100 \mathrm{mg} / \mathrm{kgBB} / \mathrm{hr}\end{array}$ & 6 & $210,32 \pm 0,12$ & \\
\hline $\mathrm{P}_{2}$ & $\begin{array}{l}\text { Fraksi etil asetat } \\
100 \mathrm{mg} / \mathrm{kgBB} / \mathrm{hr}\end{array}$ & 6 & $210,44 \pm 0,13$ & \\
\hline $\mathrm{P}_{3}$ & $\begin{array}{l}\text { Fraksi etanol air } \\
100 \mathrm{mg} / \mathrm{kgBB} / \mathrm{hr}\end{array}$ & 6 & $210,38 \pm 0,20$ & \\
\hline
\end{tabular}

Berdasarkan Tabel 3 terlihat rata-rata berat tikus strain Sprague Dawley pada kelompok kontrol 210,28 $\pm 0,11, \quad$ Fraksi n-heksan $210,32 \pm 0,12$, Fraksi etil asetat $210,44 \pm 0,13$, Fraksi etanol air 210,38 $\pm 0,20$. Hasil uji statistik didapatkan nilai $p$-value $0,326(p>0,05)$. Hal ini menunjukkan bahwa berat badan tikus homogen dan memenuhi persyaratan dalam penelitian eksperimental sehingga penelitian dapat dilanjutkan.

\begin{tabular}{|c|c|c|c|c|}
\hline Kelompok & Perlakuan & $\mathbf{n}$ & $\begin{array}{c}\text { Berat } \\
\text { Epididimis (mg) } \\
\overline{\mathbf{x}} \pm \mathrm{SD}\end{array}$ & $\begin{array}{c}p- \\
\text { value }\end{array}$ \\
\hline $\mathrm{K}_{1}$ & CMC $1 \%$ & 6 & $0,386 \pm 0,020 \mathrm{a}$ & \multirow{4}{*}{0,000} \\
\hline$P_{1}$ & $\begin{array}{l}\text { Fraksi n-heksan } \\
100 \mathrm{mg} / \mathrm{kgBB} / \mathrm{hr}\end{array}$ & 6 & $0,421 \pm 0,022 \mathrm{ab}$ & \\
\hline $\mathrm{P}_{2}$ & $\begin{array}{l}\text { Fraksi etil asetat } \\
100 \mathrm{mg} / \mathrm{kgBB} / \mathrm{hr}\end{array}$ & 6 & $0,503 \pm 0,064 \mathrm{c}$ & \\
\hline $\mathrm{P}_{3}$ & $\begin{array}{l}\text { Fraksi etanol air } \\
100 \mathrm{mg} / \mathrm{kgBB} / \mathrm{hr}\end{array}$ & 6 & $0,450 \pm 0,034 \mathrm{~b}$ & \\
\hline
\end{tabular}

Berdasarkan Tabel 4 terlihat bahwa hasil uji ANOVA antara kelompok perlakuan didapatkan $p$-value $=0,000(p<0,05)$ yang berarti bahwa ada perbedaan bermakna rerata berat epididimis antar kelompok perlakuan. Berdasarkan hal ini maka dapat dilanjutkan dengan uji Duncan didapatkan bahwa fraksi etil asetat $\left(\mathrm{P}_{2}\right)$ lebih efektif meningkatkan berat epididimis tikus putih jantan. 
Tabel 5. Pengaruh Pemberian Fraksi Daun Kemangi terhadap Diameter Tubulus Cauda Epididimis Tikus Putih Jantan pada Kelompok Kontrol dan Perlakuan

\begin{tabular}{clccc}
\hline Kelompok & Perlakuan & n & $\begin{array}{c}\text { Diameter Tubulus } \\
\text { Cauda Epididimis } \\
(\mu \mathbf{m}) \overline{\mathbf{x}} \pm \mathrm{SD}\end{array}$ & $\begin{array}{c}\boldsymbol{p} \text { - } \\
\text { value }\end{array}$ \\
\hline $\mathrm{K}_{1}$ & CMC 1\% & 6 & $453,99 \pm 71,64 \mathrm{a}$ & \\
$\mathrm{P}_{1}$ & $\begin{array}{l}\text { Fraksi n-heksan } \\
\text { 100mg/kgBB/hr }\end{array}$ & 6 & $624,29 \pm 95,83 \mathrm{bc}$ & \\
& $\begin{array}{l}\text { Fraksi etil asetat } \\
\mathrm{P}_{2}\end{array}$ & 6 & $712,27 \pm 93,84 \mathrm{c}$ & 0,000 \\
& $\begin{array}{l}\text { 100mg/kgBB/hr } \\
\text { Fraksi etanol air }\end{array}$ & 6 & & \\
$\mathrm{P}_{3}$ & $100 \mathrm{mg} / \mathrm{kgBB} / \mathrm{hr}$ & 6 & $555,52 \pm 70,89 \mathrm{~b}$ & \\
\hline
\end{tabular}

Berdasarkan Tabel 5 terlihat bahwa hasil uji ANOVA antara kelompok perlakuan didapatkan $p$-value $=0,000(p<0,05)$ yang berarti terdapat perbedaan bermakna rerata diameter cauda epididimis antar kelompok perlakuan. Berdasarkan hasil ini maka dapat dilanjutkan dengan uji Duncan didapatkan bahwa fraksi etil asetat $\left(\mathrm{P}_{2}\right)$ lebih efektif meningkatkan diameter tubulus cauda epididimis tikus putih jantan.

Tabel 6. Pengaruh Pemberian Fraksi Daun Kemangi Terhadap Tebal Epitel Epididimis Tikus Putih Jantan pada Kelompok Kontrol dan Perlakuan

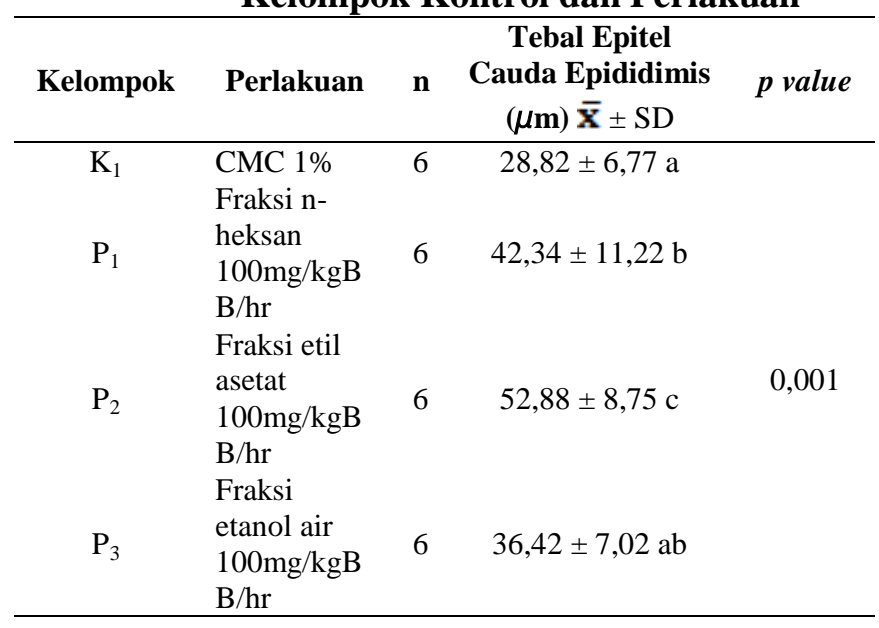

Berdasarkan Tabel 6 terlihat bahwa hasil uji ANOVA antara kelompok perlakuan didapatkan $p$-value $=0,001 \quad(p<0,05)$ yang berarti terdapat perbedaan bermakna rerata diameter tebal epitel cauda epididimis antar kelompok perlakuan. Berdasarkan hasil ini maka dapat dilanjutkan dengan uji Duncan didapatkan bahwa fraksi etil asetat $\left(\mathrm{P}_{2}\right)$ lebih efektif meningkatkan tebal epitel cauda epididimis tikus putih jantan.
Tabel 7. Pengaruh Pemberian Fraksi Daun Kemangi terhadap Motilitas Spermatozoa Tikus Putih Jantan pada Kelompok Kontrol dan Perlakuan

\begin{tabular}{|c|c|c|c|c|}
\hline Kelompok & Perlakuan & $\mathbf{n}$ & $\begin{array}{c}\text { Motilitas } \\
\text { Spermatozoa } \\
(\%) \overline{\mathbf{x}} \pm \text { SD }\end{array}$ & $\begin{array}{c}p- \\
\text { value }\end{array}$ \\
\hline$\overline{\mathrm{K}_{1}}$ & CMC $1 \%$ & 6 & $33,00 \pm 15,07 \mathrm{a}$ & \multirow{4}{*}{0,002} \\
\hline $\mathrm{P}_{1}$ & $\begin{array}{l}\text { Fraksi n-heksan } \\
100 \mathrm{mg} / \mathrm{kgBB} / \mathrm{hr}\end{array}$ & 6 & $45,17 \pm 10,30 \mathrm{ab}$ & \\
\hline $\mathrm{P}_{2}$ & $\begin{array}{l}\text { Fraksi etil asetat } \\
100 \mathrm{mg} / \mathrm{kgBB} / \mathrm{hr}\end{array}$ & 6 & $62,50 \pm 6,71 \mathrm{c}$ & \\
\hline $\mathrm{P}_{3}$ & $\begin{array}{l}\text { Fraksi etanol air } \\
100 \mathrm{mg} / \mathrm{kgBB} / \mathrm{hr}\end{array}$ & 6 & $50,00 \pm 10,75 \mathrm{bc}$ & \\
\hline
\end{tabular}

Berdasarkan Tabel 7 terlihat bahwa hasil uji ANOVA antara kelompok perlakuan didapatkan $p$-value $=0,002(p<0,05)$ yang berarti terdapat perbedaan bermakna rerata motilitas spermatozoa antar kelompok perlakuan. Berdasarkan hasil ini maka dapat dilanjutkan dengan uji Duncan didapatkan bahwa fraksi etil asetat $\left(\mathrm{P}_{2}\right)$ lebih efektif meningkatkan motilitas spermatozoa tikus putih jantan.

Tabel 8. Pengaruh Pemberian Fraksi Daun Kemangi terhadap Viabilitas Spermatozoa Tikus Putih Jantan pada Kelompok Kontrol dan Perlakuan

\begin{tabular}{|c|c|c|c|c|}
\hline Kelompok & Perlakuan & $\mathbf{N}$ & $\begin{array}{c}\text { Viabilitas } \\
\text { Spermatozoa } \\
(\%) \overline{\mathbf{x}} \pm \text { SD }\end{array}$ & $\begin{array}{c}p- \\
\text { value }\end{array}$ \\
\hline $\mathrm{K}_{1}$ & CMC $1 \%$ & 6 & $47,17 \pm 10,61 \mathrm{a}$ & \multirow{4}{*}{0,001} \\
\hline $\mathrm{P}_{1}$ & $\begin{array}{l}\text { Fraksi n-heksan } \\
100 \mathrm{mg} / \mathrm{kgBB} / \mathrm{hr}\end{array}$ & 6 & $57,50 \pm 6,53 a b$ & \\
\hline $\mathrm{P}_{2}$ & $\begin{array}{l}\text { Fraksi etil asetat } \\
100 \mathrm{mg} / \mathrm{kgBB} / \mathrm{hr}\end{array}$ & 6 & $73,00 \pm 7,87 \mathrm{c}$ & \\
\hline $\mathrm{P}_{3}$ & $\begin{array}{l}\text { Fraksi etanol air } \\
100 \mathrm{mg} / \mathrm{kgBB} / \mathrm{hr}\end{array}$ & 6 & $64,65 \pm 9,83 \mathrm{bc}$ & \\
\hline
\end{tabular}

Berdasarkan Tabel 8 terlihat bahwa hasil uji ANOVA antara kelompok perlakuan didapatkan $p$-value $=0,001 \quad(p<0,05)$ yang berarti terdapat perbedaan bermakna rerata viabilitas spermatozoa antar kelompok perlakuan. Berdasarkan hasil ini maka dapat dilanjutkan dengan uji Duncan didapatkan bahwa fraksi etil asetat $\left(\mathrm{P}_{2}\right)$ lebih efektif meningkatkan viabilitas spermatozoa tikus putih jantan.

\section{PEMBAHASAN}

Ekstraksi, Fraksinasi dan Golongan Senyawa
Daun Kemangi (Ocimum americanum L.)

Dalam penelitian ini terlihat bahwa hasil fraksinasi dengan pelarut etanol air memiliki berat yang lebih besar dibandingkan dengan fraksi n-heksan dan etil asetat. Hal ini disebabkan 
karena pelarut etanol bersifat polar yang akan melarutkan senyawa polar yang terdapat dalam protoplasma seperti flavonoid. Dari ketiga hasil fraksi tersebut dilakukan uji skrining fitokimia untuk menentukan golongan senyawa yang terkandung dari masing-masing fraksi. Dari hasil skrining, menunjukkan pada fraksi n-heksan mengandung senyawa tanin, saponin, flavonoid.

Pada fraksi etil asetat terdapat senyawa metabolit sekunder berupa steroid, terpenoid, saponin dan flavonoid. Sedangkan pada fraksi etanol air terdapat steroid, terpenoid, saponin dan flavonoid. Dari ketiga fraksi tersebut, ditemukan senyawa yang paling aktif dan terdapat di seluruh fraksi yaitu flavonoid yang ada di dalam fraksi etil asetat.

Hal ini sejalan dengan penelitian Pemayun et al (2007), bahwa tingkat kepolaran yang berbeda-beda akan menghasilkan polifenol yang berbeda sehingga sifat antioksidan yang dimiliki oleh setiap senyawa dari ekstraksi juga akan berbeda. Menurut Rohman et al (2006), pelarut etil asetat sangat cocok untuk proses ekstraksi senyawa fenolik. Aktivitas antioksidan berbanding lurus dengan total fenol maka semakin tinggi kandungan fenol dalam suatu bahan semakin meningkat pula aktifitasnya sebagai antioksidan.

\section{Berat Epididimis}

Epididimis merupakan saluran yang mengubungkan kelenjar testis dan vas deferens dan dapat dilakukan pengamatan secara makroskopis.

Dalam penelitian ini, bagian epididimis tikus putih jantan yang digunakan oleh peneliti yaitu bagian cauda epididimis dimana tempat menyimpan sperma yang telah matang dan dipisahkan dari bagian kaput dan korpus epididimis. Senyawa steroid merupakan salah satu bahan baku untuk sintesis hormon testosteron (Sastroamidjojo, 1997). Di dalam senyawa steroid, Winarto (1997) menyatakan bahwa steroid mampu menghambat enzim yang mengkatalis konversi androgen menjadi estrogen sehingga konsentrasi hormon testosteron meningkat. Hormon testosteron meningkat dapat mempengaruhi berat epididimis juga mengalami peningkatan yang menandakan bahwa produksi spermatozoa dapat mengalami pematangan dan tersimpan di dalam cauda epididimis secara optimal.

Pada fraksi etil asetat memiliki aktifitas lebih besar dalam meningkatkan berat epididimis, hal ini dipengaruhi oleh senyawa flavonoid dan steroid yang terkandung di dalamnya. Hal ini sesuai dengan penelitian yang dilakukan oleh Huliselan (2015), bahwa ekstrak etil asetat memiliki kandungan total fenolik yang lebih tinggi dibandingkan dengan ekstrak etanol dan ekstrak n-heksan dari daun sesewanua.

\section{Diameter Tubulus Cauda Epididimis}

Pada kelompok perlakuan yang diberikan fraksi etil asetat lebih meningkatkan ukuran diameter tubulus cauda epididimis pada tikus putih jantan dibandingkan fraksi n-heksan, fraksi etanol air dan kelompok kontrol CMC $1 \%$.

Dari hasil yang didapatkan adanya peningkatan pada diameter tubulus cauda epididimis pada kelompok perlakuan yang diberikan fraksi etil asetat dikarenakan terdapat senyawa aktif flavonoid sebagai antioksidan eksogen dan senyawa steroid yang membantu melindungi membran plasma. Senyawa flavonoid dapat mempengaruhi proses spermatogenesis dan meningkatkan hormon testosteron yang memiliki fungsi mengatur morfologi sel epitel epididimis sehingga dapat meningkatkan jumlah sel-sel spermatogenik yang ditandai dengan meningkatnya diameter cauda epididimis pada tikus putih jantan (Sugana, 1989).

Hasil penelitian Anzila (2017), menunjukkan bahwa pada mencit jantan yang diberikan ekstrak kemangi dosis $200 \mathrm{mg} / \mathrm{kgBB}$ terjadi peningkatan jumlah sel spermatogenik yang diduga karena pengaruh senyawa yang terkandung di dalam kemangi yang menyebabkan peningkatan sekresi hormon testosteron.

Selain fraksi etil asetat, terlihat bahwa fraksi n-heksan pun memiliki pengaruh positif terhadap peningkatan diameter tubulus cauda epididimis, hal ini dipengaruhi oleh adanya senyawa flavonoid dan tanin yang bersifat fenolik. Senyawa tanin memiliki peran dalam senyawa fenol yang memiliki peran dalam menghasilkan efek antioksidan dan melindungi lipid (Zahara et al, 2014). Fraksi n-heksan memiliki sifat pelarut non-polar yang dapat menembus lipid lapis ganda dan menembus membran sehingga bekerja lebih baik sebagai antioksidan pada epididimis tikus putih jantan. 


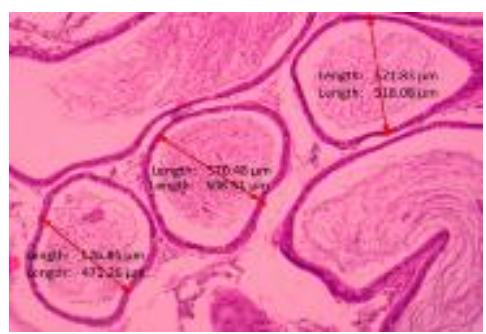

Gambar 1. Diameter tubulus cauda epididimis pada kelompok kontrol CMC $1 \%$

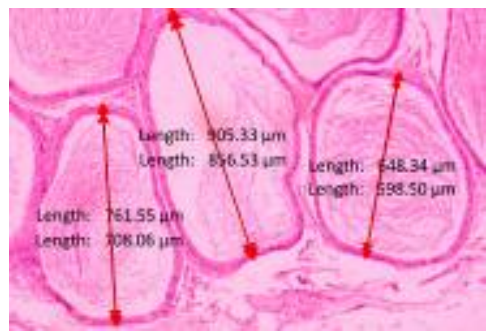

Gambar 2. Diameter tubulus cauda epididimis pada kelompok fraksi n-heksan dosis $100 \mathrm{mg} / \mathrm{kgBB} / \mathrm{hr}$

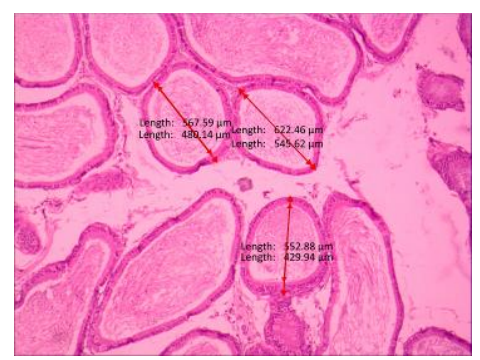

Gambar 3. Diameter tubulus cauda epididimis pada kelompok fraksi etil asetat dosis $100 \mathrm{mg} / \mathrm{kgBB} / \mathrm{hr}$

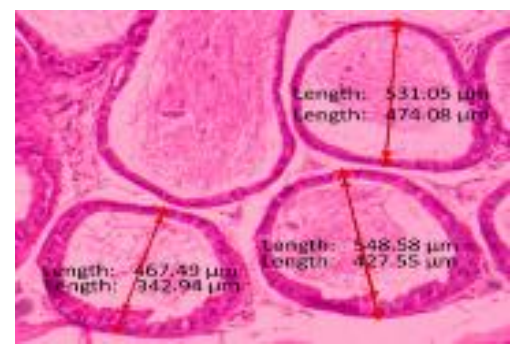

Gambar 4. Diameter tubulus cauda epididimis pada kelompok fraksi etanol air dosis $100 \mathrm{mg} / \mathrm{kgBB} / \mathrm{hr}$

\section{Tebal Epitel Cauda Epididimis}

Dari hasil pengamatan histologi epididimis menunjukkan bahwa terjadi peningkatan tebal epitel cauda epididimis yang tidak hanya dipengaruhi oleh senyawa flavonoid, tetapi senyawa steroid dan tanin yang berperan di dalam fraksi daun kemangi sehingga mempengaruhi testosteron dalam proses spermatogenesis. Testosteron berperan mengatur morfologi sel epitel epididimis sehingga epitel cauda epididimis menebal yang memberikan

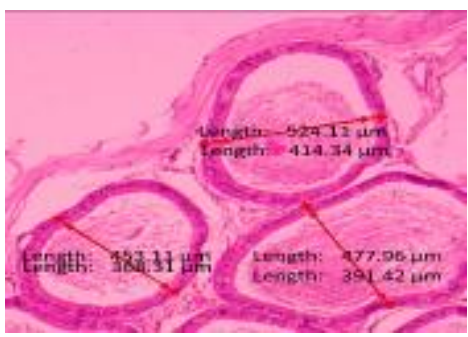

Gambar 5. Tebal epitel cauda epididimis pada kelompok kontrol CMC 1\%

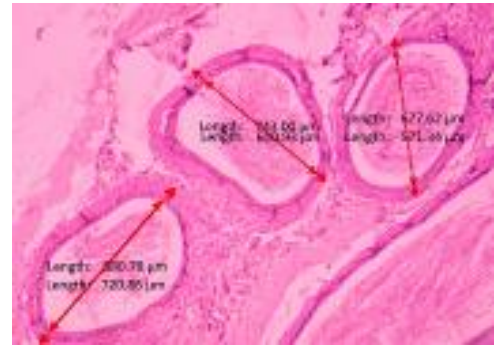

Gambar 6. Tebal epitel cauda epididimis pada kelompok fraksi n-heksan dosis $100 \mathrm{mg} / \mathrm{kgBB} / \mathrm{hr}$

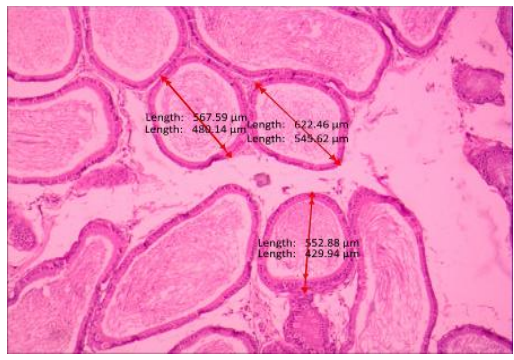

Gambar 7. Tebal epitel cauda epididimis pada kelompok fraksi etil asetat dosis $100 \mathrm{mg} / \mathrm{kgBB} / \mathrm{hr}$

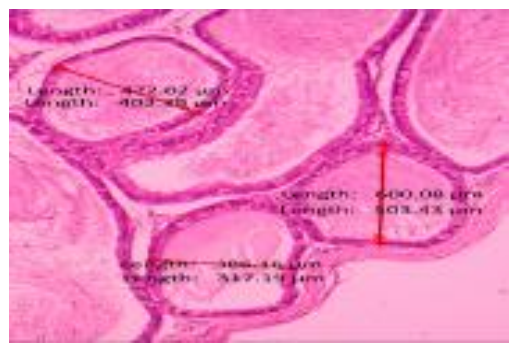

Gambar 8. Tebal epitel cauda epididimis pada kelompok fraksi etanol air dosis $100 \mathrm{mg} / \mathrm{kgBB} / \mathrm{hr}$

manfaat spermatozoa yang tersimpan menjadi lebih optimal. Tebal epitel cauda epididimis yang menebal memberikan manfaat spermatozoa yang tersimpan di dalam cauda epididimis menjadi lebih optimal.

\section{Motilitas Spermatozoa}

Dari hasil penelitian didapatkan peningkatan motilitas spermatozoa pada kelompok fraksi etil asetat sebesar $62,50 \%$. Motilitas spermatozoa dipengaruhi oleh beberapa 
fase kehidupan dan perilaku tikus. Umur tikus putih jantan dalam penelitian ini 60-74 hari yang termasuk dalam fase kematangan seksual (Sengupta, 2013).

Hormon LH dan FSH dari hipofisis anterior memegang peranan penting dalam mengatur reproduksi pada hewan jantan. FSH merangsang proses spermatogenesis, sedangkan LH/ ICSH (Interstitial Cell Stimulating Hormone) merangsang pertumbuhan dan metabolisme sel-sel Leydig dan memproduksi hormon testosteron. Sel germinal yang didukung oleh sel sertoli sangat mempengaruhi efisiensi spermatogenesis (Boekelheide et al., 2000).

Spermatozoa membutuhkan gerakan motilitas progresif (forward motility) dan kemampuan proses fertilisasi sel telur selama melewati epididimis (Zhan et al, 2012). Proses glikolisis dalam proses pematangan spermatozoa akan menghasilkan energi berupa Adenosin Tri Phosphat (ATP). ATP digunakan oleh spermatozoa sebagai sumber energi sehingga spermatozoa tetap dapat motil serta mempertahankan daya hidupnya (Souhoka et al, 2009). Terdapat dua faktor yang memengaruhi motilitas spermatozoa meliputi faktor endogen yaitu persediaan energy (ATP), pematangan spermatozoa serta integritas membran sel, sedangkan faktor eksogen dari nutrisi yang memengaruhi motilitas spermatozoa adalah ketersediaan ion anorganik. ATP dibutuhkan untuk kontraksi/pergerakan spermatozoa (Hafez, 2000).

\section{Viabilitas Spermatozoa}

Perhitungan viabilitas spermatozoa dilakukan untuk mengetahui kualitas spermatozoa karena sangat berpengaruh terhadap pembuahan. Pengamatan viabilitas berdasarkan sperma hidup dan mati yang dilakukan pada 200 sel spermatozoa dibawah mikroskop cahaya dengan pembesaran 400x. Spermatozoa yang hidup tidak akan terwarnai oleh Eosin $Y$ sedangkan spermatozoa yang telah mati akan berwarna merah keunguan dikarenakan rusaknya membran plasma sel spermatozoa. Penentuan viabilitas spermatozoa dinyatakan dalam persen 100\% (WHO, 2010).

Dalam penelitian ini, viabilitas spermatozoa mengalami peningkatan pada kelompok perlakuan fraksi etil asetat sebesar 73\% dibandingkan pada kelompok perlakuan fraksi etanol air sebesar $64,65 \%$, pada kelompok perlakuan fraksi n-heksan sebesar 57,50\% dan kelompok kontrol spermatozoa yang hidup sebesar $47,17 \%$. Kemampuan daya hidup berhubungan dengan kecukupan nutrisi dan energi dalam semen. Plasma semen mengandung protein, asam askorbat, natrium, kalium dan kalsium (Nurcholidah et al, 2008), fruktosa dan glikoprotein yang membungkus permukaan spermatozoa (Norman et al, 1987; Johnson \& Barry, 1998).

Pada fraksi etil asetat (dosis 100 $\mathrm{mg} / \mathrm{KgBB} / \mathrm{hr}$ ) selama 36 hari lebih efektif meningkatkan viabilitas spermatozoa pada tikus putih jantan dibandingkan dengan fraksi etanol air $(100 \mathrm{mg} / \mathrm{KgBB} / \mathrm{hr})$, fraksi n-heksan (100 $\mathrm{mg} / \mathrm{KgBB} / \mathrm{hr}$ ), dan kelompok kontrol yang diberikan $\mathrm{CMC} 1 \%$. Hal ini sejalan dengan penelitian yang dilakukan oleh Musfirah (2016), pada akar ekstrak etanol 70\% akar saluang balum mengandung senyawa steroid dan flavonoid yang mampu mempertahankan kualitas sperma dengan mempertahankan motilitas sperma dan mampu melindungi membran spermatozoa sehingga meningkatkan viabilitas sperma dan meningkatkan jumlah sperma.

Peneliti mengamati pada spermatozoa yang mati terlihat berwarna merah keunguan sedangkan spermatozoa yang hidup tidak terwarnai oleh pewarna. Hal ini sesuai dengan penelitian Fitriani et al (2010), bahwa spermatozoa mati akan menyerap zat warna yang disebabkan oleh rusaknya membran plasma pada spermatozoa sedangkan spermatozoa yang hidup masih memiliki membran plasma yang utuh sehingga pompa natrium dapat berfungsi baik.

Viabilitas spermatozoa pada tikus putih jantan mengalami peningkatan karena dipengaruhi oleh status umur tikus 60-74 hari termasuk fase dewasa sehingga memiliki reproduksi yang matang. Hal ini sesuai dengan pendapat Sengupta (2013), menyatakan bahwa presentase spermatozoa hidup pada tikus Sprague Dawley dapat dipengaruhi oleh umur tikus.

\section{SIMPULAN}

Dari hasil penelitian pengaruh berat, diameter, tebal epitel epididimis, motilitas dan viabilitas spermatozoa tikus putih jantan setelah pemberian fraksi daun kemangi selama 36 hari dapat disimpulkan bahwa kelompok perlakuan yang diberikan fraksi etil asetat dosis $100 \mathrm{mg} / \mathrm{kgBB} / \mathrm{hr}$ selama 36 hari mampu meningkatkan berat epididimis, diameter tubulus cauda epididimis, tebal epitel cauda epididimis, motilitas dan viabilitas spermatozoa. 


\section{DAFTAR PUSTAKA}

Anzila, I., WM, A. P., Soewondo, A., \& Rahayu, S. (2017). Pengaruh Ekstrak Ethanol Kemangi (Ocimum canum Sims.) terhadap Struktur Histologi Testis Mencit (Mus musculus) Jantan. Biotropika: Journal of Tropical Biology, 5(1), 22-26.

Balaji, R., G. Prakash., Suganya, D.P. (2011). Antioxidant activity of methanol extract of ocimum tenuiflorum. Biotechnology. India.

Boekelheide, K., Fleming, S. L., Johnson, K. J., Patel, S. R., \& Schoenfeld, H. A. (2000). Role of Sertoli cells in injury-associated testicular germ cell apoptosis. Proceedings of the Society for Experimental Biology and Medicine: Minireview, 225(2), 105 115 .

Cornwall, G.A. (2009). New insights into epididymal biology and function. Human Reproduction Update; 15(2) pp. 213-227.

Fitriani, K., Eriani and W. Sari. (2010). The effect of cigarettes smoke exposure causes fertility of male mice (Mus musculus). Jurnal Natural. 10(2):12-17.

Hafez, B. \& E.S.E Hafez. (2000). Reproduction In farm animals. Lea and Febiger, Philadelpia.

Huliselan, Y. M. (2015). Aktivitas Antioksidan Ekstrak Etanol, Etil Asetat, dan n-Heksan dari Daun Sesewanua (Clerodendron squamatum Vahl.). Pharmacon, 4(3), 155163.

Johnson MH and Barry JE. (1998). Essential reproduction. London. Blackwell Science Ltd.

Jones, R. (2004). Sperm Survival Versus Degradation in the Mammalian Epididymis: A Hypothesis. Biology of Reproduction, 71:1405-1411.

Musfirah, Y., Bachri, M.S., Nuraini, L.H. (2016). Efek ekstrak etanol $70 \%$ akar saluang balum terhadap spermatogenesis dan gambaran histopatologik testis mencit. Jurnal Pharmascience, Vol.03 No.02: 131-141.

Naz \& Rajendran Sellamuthu. (2006). Receptor in Spermatozoa: Are They Real?. Journal Andrology, Vol. 7 No. 25.

Norman AW and Litwack G. (1987). Hormones. London, Sidney, Tokyo: Academic Press Inc.

Nurcholidah, SR, S. Darodjah, M. Rizal, M. Fitriati. (2008). Kualitas Spermaotozoa Kauda Epididimis Sapi Peranakan Ongol (PO) dalam Pengencer Susu, Tris, Sirat
Kuning Telur pada Penyimpanan $4-5^{\circ} \mathrm{C}$. Anim Prod. 10(1) : 22-29.

Palupi, H.D. (2006). Pengaruh pemberian jus buah tomat terhadap viabilitas spermatozoa mencit Balb/c jantan yang diberi paparan asap rokok. (Skripsi, Universitas Diponegoro Semarang).

Pemayun, T. G. O. (2007). Kadar Prostaglandin F2? pada Cairan Vesikula Seminalis dan Produk Sel Monolayer Vesikula Seminalis Sapi Bali (CONCENTRATIONS OF PROSTAGLANDIN F2? IN SEMINAL VESICLE FLUID AND PRODUCT OF SEMINAL VESICLE MONOLAYER CELLS OF BALI CATTLE). Jurnal Veteriner, 8(4).

Riskesdas. (2013). Riset Kesehatan Dasar. Jakarta: Kementrian Kesehatan RI.

Rohman, A., Sugeng, R. (2006). Aktivitas antioksidan, kandungan fenolik total, dan kandungan flavonoid total ekstrak etil asetat buah mengkudu serta fraksifraksinya. Majalah farmasi Indonesia: 17(3), 136-142.

Safwan, dkk. (2016). Pengaruh ekstrak daun kemangi terhadap motilitas dan konsentrasi spermatozoa mencit jantan (Mus musculus). Jurnal Ilmiah Ibnu Sina 1.

Sarma D, Sai Koteswar and Babu, A. Venka Suresh. (2011). Pharmacognostic and Phytochemical Studies of Ocimum americanum. Jurnal of Chemical and Pharmaceutical Research. Volume 3.

Sastroamidjojo, S. (1997). Obat Asli Indonesia. Jakarta: Dian Rakyat.

Sengupta, P. (2013). The laboratory rat: relating its age with human's. International journal of preventive medicine, 4(6), 624.

Siburian, J., \& Marlinza, R. (2009). Efek Pemberian Ekstrak Akar Pasak Bumi (Eurycoma Longifolia Jack) Pada Tahap Prakopulasi Terhadap Fertilitas Mencit (Mus Musculus L.) Betina. Jurnal Biospesies. Jambi: Universitas Jambi, 2(2).

Souhoka, D.F., Matatula, M.J., Mesang-Nalley, W.M. dan Rizal, M. (2009). Laktosa mempertahankan daya hidup spermatozoa kambing peranakan etawah yang dipreservasi dengan plasma semen domba priangan. J. Vet. 10: 135-142.

Sugana. (1989). Penampilan Reproduksi dan Pertumbuhan Tikus Putih (Rattus rattus). Media Perternakan, 11: 94-103.

Wahyuni, S., Agungpriyono, S., Agil, M., dkk. (2012). Histologi dan Histomorfometri 
Testis dan Epididimis Muncak (Muntiaws Muncak) Pada Periode Ranggah Keras. Jurnal Veteriner, Vol.13 No.3:211-219.

WHO. (2010). Laboratory Manual For The Examination and Processing Of Human Semen, $5^{\text {th }}$ ed.

Winarto W, Sundari D. (1997). Informasi Tanaman Obat untuk Kontrasepsi Tradisional. Cermin Dunia Kedokteran, 120: 25-28.
Zahara, K., Bibi, Y., Tabassum, S. (2014). Clinical and therapeutic benefits of $\mathrm{C}$. asiatica. Pure Appl Bio, 3:152-9

Zhan XC, Wang A, Liu, Y. Zhang. (2012). Region Specific Localization of IMDS 60 Protein in Mouse Epididymis and its Relationship With Sperm Maturation. Acta Biochim Biophys Sin, 44 (11): 924-930. 